\title{
INVESTIGATION OF THE PHYLOGENETIC RELATIONSHIPS OF SARCOCYSTIS SPP. FROM GREYLAG (ANSER ANSER) AND WHITE-FRONTED (ANSER ALBIFRONS) GEESE TO OTHER CYST FORMING COCCIDIA USING 18S AND 28S rRNA GENE SEQUENCES
}

\author{
Dalius BUTKAUSKAS, Aniolas SRUOGA, Liuda KUTKIENĖ, Petras PRAKAS
}

Institute of Ecology of Vilnius University, Akademijos 2, LT-08412 Vilnius-21, Lithuania. E-mail: dalius@ekoi.lt

\begin{abstract}
Based on cyst morphology, Sarcocystis cysts type I were found in one White-fronted goose (Anser albifrons) and cysts type III in one Greylag goose (Anser anser) and two White-fronted geese. Sarcocysts isolated from infected birds as intermediate host have not been previously described and are unnamed. Type III sarcocysts detected in White-fronted and Greylag geese may illustrate the case of polyhostal nature of sarcocysts when same-species parasites infest intermediate hosts of different species. The obtained partial sequences of $18 \mathrm{~S}$ and $28 \mathrm{~S}$ ribosomal RNA showed the highest homology for the genera Sarcocystis and Frenkelia. In the tree of phylogenetic relationships, the species involved in this study were grouped with Frenkelia microti, Frenkelia glareoli, Sarcocystis muris and Sarcocystis neurona. Analysis of the partial sequences of $18 \mathrm{~S}$ and $28 \mathrm{~S}$ ribosomal RNA revealed the phylogenetic and taxonomic status of the investigated Sarcocystis spp.
\end{abstract}

Key words: Sarcocystis, $18 \mathrm{~S}$ and 28S rRNA genes, phylogenetic relationships

\section{INTRODUCTION}

The family Sarcocystidae is distinguishable from other coccidia by a two-host life cycle, the ability to form cysts in different tissues of intermediate hosts and the morphology of oocystes (Frenkel 1977; Dubey 1993). The classification and taxonomy of this family is very problematic and based on phenotypic characteristics. Sarcocystis and Frenkelia belong to the subfamily Sarcocystinae due to their in host development and an obligatory two-host life cycle (Levine 1988; Lindsay \& Todd 1993). The host spectrum of Sarcocystis species is very broad: mammals, birds and ectothermal animals. Some of sarcocyst species are pathogenic organisms dangerous to humans and livestock (Yang et al. 2001).

Analysis of small- and large-subunit rRNA coding sequences is successfully applied in phylogenetic studies of the family Sarcocystidae (Dolezel et al. 1999; Mugridge et al. 2000; Elsheikha et al. 2005). 18S and 28S rRNA genes are distinguishable by their sufficient length, universal distribution, optimal ratio between constant and variable fragments and by comparatively simple selection of primers. The lack of comprehensive studies on Sarcocystis species infecting birds as intermediate hosts poses a problem. The greatest attention has been given to the members of the
Anseriformes order. Several types of Sarcocystis cysts were detected in Anseriformes (Wobeser et al. 1981; Kutkienè \& Sruoga 2004; Kutkienè et al. 2006), but only the final host of Sarcocystis rileyi was identified (Dubey et al. 2003). Little is known about Sarcocystis species parasitising Anseriformes (Kutkienè \& Sruoga 2004; Kutkiene et al. 2006). The main aim of this work was to compare Sarcocystis species infecting different Anseriformes species and to determine their taxonomic status in the family Sarcocystidae using partial $28 \mathrm{~S}$ and $18 \mathrm{~S}$ rRNA gene sequences.

\section{MATERIAL AND METHODS}

Sarcocystis spp. cysts were found in the neck muscles of one Greylag (Anser anser) and three White-fronted (Anser albifrons) geese hunted in the Nemunas River Delta and the Curonian Spit in 2004 and 2005. Cyst morphology was studied using light and electron microscopes (Kutkienè et al. 2006). Cysts were differentiated according to the thickness of their walls, as well as the length and shape of wall projections. Based on cyst morphology (Kutkienè \& Sruoga 2004) the analysed sarcocysts represented Sarcocystis sp. (Anser anser cyst type III), Sarcocystis sp. (Anser albifrons cyst type III) and Sarcocystis sp. (Anser albifrons cyst type I). 
The genomic DNA was extracted by the universal salt extraction method (Aljanabi \& Martinez 1997). The amplification of the 28S rRNA gene fragment was performed using the primer pair KL5a and KL2 (Mugridge et al. 1999), whereas of the 18S rRNA gene fragment using the primer pair $1 \mathrm{~L}$ and $1 \mathrm{H}$ (Yang et al. 2001). Polymerase chain reaction (PCR) was performed in a $25 \mu \mathrm{l}$ total volume containing $2.5 \mu 110 \times$ PCR buffer, $2.5 \mu 1$ $2 \mathrm{mM}$ dNTP mix, $0.1 \mu \mathrm{M}$ each primer, $0.5 \mu \mathrm{l}$ Taq polymerase, $2.5 \mu \mathrm{MgCl}_{2}, 0.2 \mu \mathrm{g}$ genomic DNA and the remaining volume of water. Following the initial $3 \mathrm{~min}$ denaturation step at $94^{\circ} \mathrm{C}, 30$ amplification cycles were carried out at $94^{\circ} \mathrm{C}$ for $45 \mathrm{~s}$ and at $65^{\circ} \mathrm{C}$ (KL5a/KL2) or $62^{\circ} \mathrm{C}(1 \mathrm{~L} / 1 \mathrm{H})$ for $45 \mathrm{~s}$, extension at $72^{\circ} \mathrm{C}$ for $1 \mathrm{~min}$ and a final extension of 5 minutes at $72^{\circ} \mathrm{C}$. Amplification products were purified for sequencing using a CycloPure gel extraction kit (Amresco, USA). Partial gene sequences were analysed with an ABI Prism 377 automatic DNA sequencer using the same primers as in PCR. The specificity of the end sequences was analysed with the BLAST programme comparing the identified sequences with those stored in the Gene Bank and having the highest homology for the newly identified sequences (http://www.ncbi.nlm.nih.gov/BLAST/). Comparison of gene sequences with the identified homological sequences of Sarcosystis species, estimation of genetic distances and reconstruction of phylogenetic relationships in the Sarcocystidae family were performed using the MEGA 3.1 programme (Kumar et al. 2004). The relative sequence difference expressed in percentage was determined by the FASTA programme (http://fasta.bioch. virginia.edu.).

\section{RESULTS AND DISCUSSION}

Sarcocysts isolated from four birds were analysed. Based on cyst wall morphology, type I sarcosycts recorded in one White-fronted goose had a smooth wall surface. One Greylag and two White-fronted geese were infected with type III sarcocysts possessing teat or finger-like protrusions on their walls. Sarcocysts found in birds as intermediate hosts according to their morphological characteristics were attributed to none of the known Sarcocystis species in birds.

Gene fragments of 28S rRNA 645-649 bp and 18S rRNA 1391-1393 bp in length were obtained in this study. The amplification and sequencing of only $18 \mathrm{~S}$ rRNA of Sarcocystis sp. (Anser anser cyst type III) was unsuccessful due to the degraded DNA.

Bird-infecting sarcocysts display a high level of homology. The percentage identity of the analysed sequences varied from 97.22 to $99.66 \%$. Sarcocystis sp.
(Anser albifrons cyst type I) according to the partial $18 \mathrm{~S}$ rRNA gene sequence is most closely allied to Frenkelia microti. In all other cases, the newly isolated sarcocysts according to partial $18 \mathrm{~S}$ and $28 \mathrm{~S}$ rRNA sequences are characterised by a high level of homology. Analysis of partial 18S and 28S rRNA sequences of Sarcocystis sp. at the intraspecies level (Anser albifrons cyst type III) showed no differences in sequence arrangement between two different samples of Sarcocystis sp., derived from two different specimens of Anser albifrons, whereas the identity of the partial 28S rRNA sequence of type III sarcocysts recovered from White-fronted and Greylag geese made up even $99.66 \%$. Especially high sequence identity and morphological similarities of sarcocyst walls of type III sarcocysts from White-fronted and Greylag geese could be interpreted as the case of recent interspecies divergence or some kind of intraspecies variation. Thus, it requires additional investigations to conclude if type III sarcocysts isolated from White-fronted and Greylag geese could be classified as the same species.

Sarcocystis species for a long time was considered as showing intermediate host specificity. Nevertheless, Box et al. (1984) proved experimentally that birds of the orders Passeriformes, Psittaciformes and Columbiformes are intermediate hosts of S. falcatula. The studies of the above authors became a milestone in the formation of the opinion that some of Sarcocystis species (especially in birds) are not strictly specific for an intermediate host. Subsequent studies also showed that very similar forms of Sarcocystis cysts were detected in several Anseriformes species (Wobeser et al. 1981; Kutkienė \& Sruoga 2004). Our results partially confirm the assumption that some species of sarcosporidians in birds do not exhibit high host specificity.

The BLAST sequence comparison revealed that $18 \mathrm{~S}$ and 28S rRNA gene sequences determined in our study displayed the highest homology to the species belonging to the family Sarcocystidae, and especially to the genera Sarcocystis and Frenkelia. Frenkelia is very closely related to Sarcocystis and its taxonomic status remains the subject of discussion (Mugridge et al. 1999). In order to reconstruct phylogenetic relationships in the family Sarcocystidae and to establish the taxonomic status of the species investigated, the most homological DNA sequences of Sarcocystidae species available in the Gene Bank were compared. Sarcocystis, Frenkelia and four typical species of the other genera belonging to the Sarcocystidae family were compared using their $18 \mathrm{~S}$ and $28 \mathrm{~S}$ rRNA gene sequences. Sarcocystis cf. falcatula and Sarcocystis lindsayi with a high level of homology were excluded from phylogenetic analysis, because their 18S rDNA 
sequences were not obtained, as well as Sarcocystis mucosa for the lack of data on its 28S rDNA sequence. The phylogenetic cluster analysis of the family Sarcocystidae was made following the neighbour-joining method (Fig. 1). In the dendrogram based on comparison of partial $18 \mathrm{~S}$ and $28 \mathrm{~S}$ rRNA gene sequences, the following three groups were distinguished: the first involved the investigated species grouped with Frenkelia microti, Frenkelia glareoli, Sarcocystis muris and Sarcocystis neurona, the second included Sarcocystis species, and the third embraced typical representatives of the four genera of the family Sarcocystidae. As seen from the phylogenetic tree, the genus
Sarcocystis is a paraphyletic group. Sarcocystis sp. (Anser albifrons cyst type I) forms a separate branch in the dendrogram, whereas Sarcocystis sp. (Anser albifrons cyst type III) is joined with Sarcocystis neurona, but the latter branch should be interpreted as unreliable. It is notable that the phylogenetic tree derived using partial $18 \mathrm{~S}$ and $28 \mathrm{~S}$ rRNA gene sequences is highly reproducible for groups I and II and embraces Sarcocystis species and group III, which includes typical representatives of the other genera of the family Sarcocystidae. Data show the suitability of rRNA subunits coding DNA as molecular markers in phylogenetic and taxonomic studies of the family Sarcocystidae.

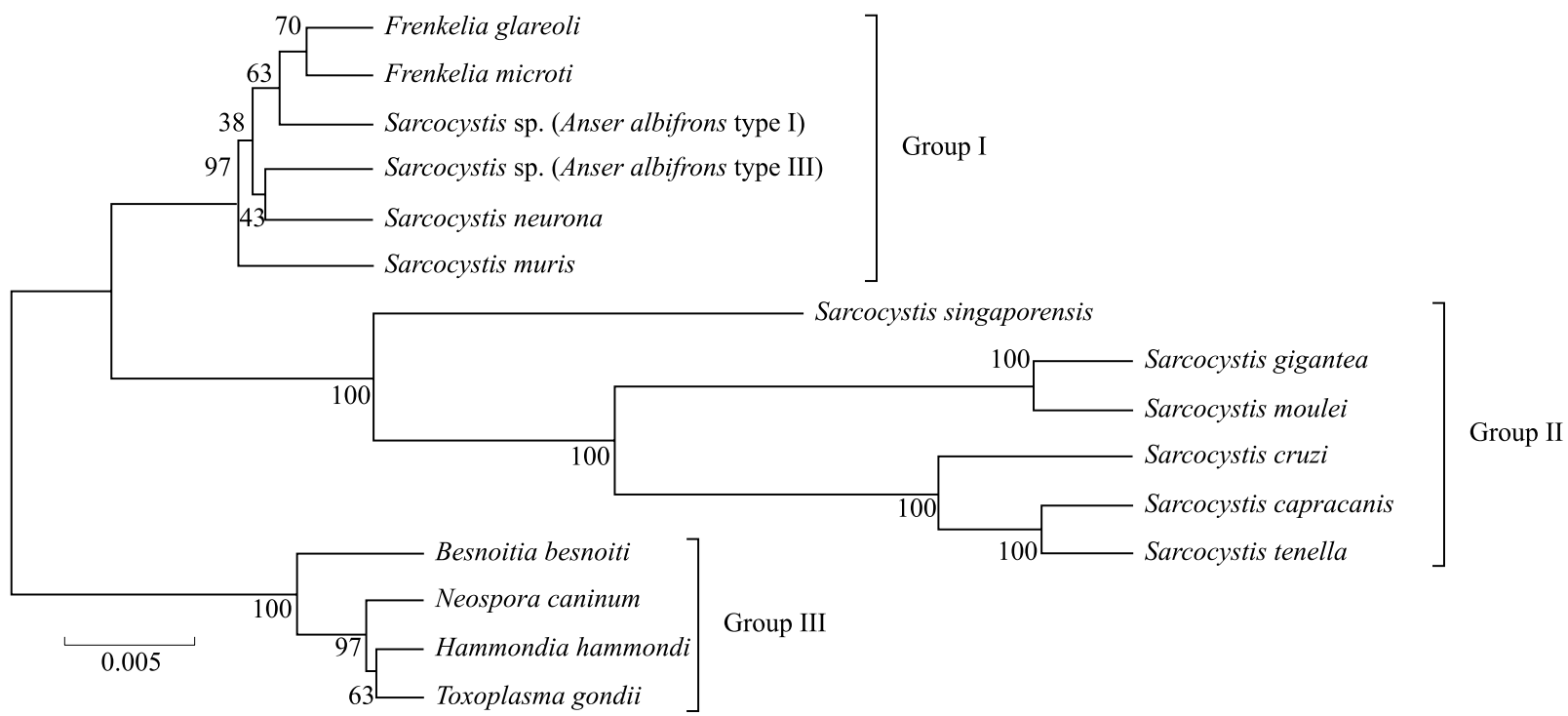

Figure 1. The phylogenetic midpoint-rooted tree of the family Sarcocystidae based on partial $18 \mathrm{~S}$ and $28 \mathrm{~S}$ rRNA sequences. The numbers show bootstrapping values (in percentage), the scale bar represents a genetic distance (0.5 substitutions per 100 nucleotides).

Table 1. Relative percentage difference in the subfamily Sarcocystinae based on comparison of partial $18 \mathrm{~S}$ and $28 \mathrm{~S}$ rRNA gene sequences.

\begin{tabular}{lcccccccccccc}
\hline & 1 & 2 & 3 & 4 & 5 & 6 & 7 & 8 & 9 & 10 & 11 & 12 \\
\hline (1) $S$. sp. (cyst type III) & - & & & & & & & & & & & \\
(2) S. sp. (cyst type I) & 0.72 & - & & & & & & & & & \\
(3) S. neurona & 0.77 & 0.62 & - & & & & & & & & \\
(4) F. glareoli & 1.08 & 0.56 & 0.82 & - & & & & & & & \\
(5) F. microti & 1.14 & 0.56 & 0.87 & 0.61 & - & & & & & & \\
(6) S. muris & 1.39 & 1.13 & 1.29 & 1.39 & 1.44 & - & & & & & \\
(7) S. singaporensis & 3.73 & 3.79 & 3.67 & 3.73 & 3.95 & 4.17 & - & & & & \\
(8) S. capracanis & 4.69 & 4.86 & 4.70 & 4.97 & 5.14 & 4.98 & 4.42 & - & & & \\
(9) S. tenella & 5.02 & 5.19 & 5.02 & 5.30 & 5.47 & 5.36 & 4.69 & 0.77 & - & & \\
(10) S. gigantea & 4.52 & 4.69 & 4.58 & 4.80 & 4.69 & 4.85 & 4.31 & 3.61 & 3.94 & - & \\
(11) S. cruzi & 4.85 & 5.02 & 4.75 & 5.24 & 5.31 & 5.19 & 4.69 & 1.55 & 1.56 & 3.72 & - \\
(12) S. moulei & 4.47 & 4.74 & 4.64 & 4.85 & 4.75 & 4.91 & 4.34 & 3.72 & 4.01 & 0.41 & 3.93 & - \\
\hline
\end{tabular}


Comparison of partial 18S and 28S rRNA gene sequences of the subfamily Sarcocystinae showed that the difference in nucleotide substitution varied from 0.41 to $5.47 \%$ (Table 1 ). In the dendrogram, the differences in the nucleotides of the first group species are smaller than those of the second group species, varying from 0.61 to $1.39 \%$ and from 0.41 to $5.47 \%$, respectively. This reveals smaller evolutionary differences between the first group species employing birds as final or intermediate hosts than between the second group species, the life cycle of which is dominated by mammals (e.g. a mammal is an intermediate and a reptile is a final host for Sarcocystis singaporensis).

The dendrogram (not shown) based only on partial $18 \mathrm{~S}$ rRNA sequences corresponds to the phylogenetic tree of the combined partial $18 \mathrm{~S}$ and $28 \mathrm{~S}$ rRNA sequences, but lower bootstrapping values were found for this dendrogram. The dendrogram based on comparison of partial $28 \mathrm{~S}$ rRNA sequences demonstrates that the reconstructed phylogenetic relationships are slightly different than those in the 18S rRNA dendrogram, therefore indicating that the available phylogenetic signal is insufficiently strong.

Consequently, to disclose statistically significant phylogenetic relationships among Sarcocystidae, a sufficiently large fragment is necessary, in which the appropriate ratio between variable and stable segments is maintained. Comparison of continuous gene sequences coding for large and small ribosomal RNA subunits is relevant. In conclusion, we can say that sarcosporidians detected in White-fronted and Greylag geese as intermediate hosts are undescribed species and their phylogenetic status is significantly revealed by $18 \mathrm{~S}$ and 28S rRNA genes.

\section{REFERENCES}

Aljanabi, M. S. and Martinez, I. 1997. Universal and rapid Salt-extraction of high quality genomic DNA for PCRbased techniques. Nucleic Acids Research 25 (22): 1772-1773.

Box, E. D., Meier, J. L. and Smith, J. H. 1984. Description of Sarcocystis falcatula Stiles, 1893, a parasite of birds and opossums. Journal of Protozoology 31: 521-524.

Dolezel, D., Koudela, B., Jirku, M., Hypsa, V., Obornk, M., Votypka, J., Modry, D., Slapeta, J. R. and Lukes, J. 1999. Phylogenetic analysis of Sarcocystis spp. of mammals and reptiles supports the coevolution of Sarcocystis spp. with their final hosts. International Journal for Parasitology 29 (5): 795-798.

Dubey, J. P. 1993. Toxoplasma, Neospora, Sarcocystis and other cyst-forming coccidia of humans and animals.
In: J. P. Kreier (ed.) Parasitic Protozoa, 2nd ed., 6: 1158. San Diego: Academic Press.

Dubey, J. P., Cawthorn, R. J., Speer, C. A. and Wobeser, G. A. 2003. Redescription of the sarcocysts of Sarcocystis rileyi (Apicomplexa: Sarcocystidae). Journal of Eukaryotic Microbiology 50: 476-482.

Elsheikha, H. M., Lacher, D. W. and Mansfield, L. S. 2005. Phylogenetic relationships of Sarcocystis neurona of horses and opossums to other cyst-forming coccidia deduced from SSU rRNA gene sequences. Parasitology Research 97: 345-357.

Frenkel, J. K. 1977. Besnoitia wallacei of cats and rodents: with a reclassification of the cyst-forming isosporoid coccidia. Journal of Parasitology 63: 611628.

Kumar, S., Tamura, K. and Nei, M. 2004. MEGA3: Integrated software for Molecular Evolutionary Genetics Analysis and sequence alignment. Briefings in Bioinformatics 5: 150-163.

Kutkienè, L. and Sruoga, A. 2004. Sarcocystis spp. in birds of the order Anseriformes. Parasitology Research 92: 171-172.

Kutkienė, L., Sruoga, A. and Butkauskas, D. 2006. Sarcocystis sp. from White-fronted goose (Anser albiforns): cyst morphology and life cycle studies. Parasitology Research 99: 562-565.

Levine, N. D. 1988. The protozoan phylum Apicomplexa: 1. Boca Raton, FL, USA: CRC Press.

Lindsay, D. S. and Todd, K. S. 1993. Coccidia of mammals. In: J. P. Kreier (ed.) Parasitic Protozoa, $2^{\text {nd }}$ ed., 4: 89131. San Diego: Academic Press.

Mugridge, N. B., Morrison, D. A., Johnson, A. M., Luton, K., Dubey, J. P., Votypka, J. and Tenter, A. M. 1999. Phylogenetic relationships of the genus Frenkelia: a review of its history and new knowledge gained from comparison of large subunit ribosomal ribonucleic acid gene sequences. International Journal for Parasitology 29: 957-972.

Mugridge, N. B., Morrison, D. A., Jäkel, T., Heckeroth, A. R., Tenter, A. M. and Johnson, A. M. 2000. Effects of sequence alignment and structural domains of ribosomal DNA on phylogeny reconstruction for the protozoan family Sarcocystidae. Molecular Biology and Evolution 17: 1842-1853.

Wobeser, G., Leighton, F. A. and Cawthorn, R. J. 1981. Occurrence of Sarcocystis Lankester, 1882, in wild geese in Saskatchewan. Canadian Journal of Zoology 59: 1621-1624.

Yang, Z. Q., Zuo, Y. X., Ding, B., Chen, X. W., Luo, J. and Zhang, Y. P. 2001. Identification of Sarcocystis hominis-like (Protozoa: Sarcocystidae) cyst in water buffalo (Bubalus bubalis) based on 18S rRNA gene sequences. Journal of Parasitology 87 (4): 934-937. 
Pilkosios (ANSER albifrons) IR baltakaktès (ANSER ANSER) ŽĄSU S SARCOCYSTIS SPP. TYRIMAS NAUDOJANT 18S IR 28S RRNR GENU SEKAS

\section{Butkauskas, A. Sruoga, L. Kutkienè, P. Prakas}

\section{SANTRAUKA}

Pagal cistų morfologiją vienoje baltakaktèje žąsyje (Anser albifrons) nustatytos I tipo Sarcocystis cistos, o dviejose baltakaktėse žąsyse ir pilkojoje žąsyje (Anser anser) III tipo cistos. Iš šiu paukščių, kaip tarpinių šeimininkų, išskirtos sarkocistos yra neapibūdintos rūšys. Iš baltakak- tès bei pilkosios žąu išskirtos III tipo sarkocistos gali būti tos pačios sarkocistų rūšies parazitavimo skirtingu rūšiu tarpiniuose šeimininkuose atvejis. Nustatytos $18 \mathrm{~S}$ ir 28S rRNR genų dalinès sekos pasižymėjo didžiausia homologija Sarcocystis bei Frenkelia gentims. Filogenetinių ryšiu medyje šiame darbe tiriamos rūšys sugrupuojamos su Frenkelia microti, Frenkelia glareoli, Sarcocystis muris ir Sarcocystis neurona. $18 \mathrm{~S}$ ir $28 \mathrm{~S}$ rRNR dalinių sekų analizè atskleidžia tirtų Sarcocystis spp. rūšių filogenetinę bei taksonominę padèti.

Received: 21 December 2006 Accepted: 2 May 2007 